\title{
Aggressive mosquito fauna and malaria transmission in a forest area targeted for the creation of an agro-industrial complex in the south of Cameroon
}

\author{
P. Ntonga Akono, ${ }^{1}$ C. Tonga, ${ }^{1}$ O.E. Ngo Hondt, ${ }^{1}$ M.F. Peka Nsangou, ${ }^{2}$ R. Ngaha, ${ }^{1}$ \\ G. Tamdem Magne, ${ }^{1}$ L. Youmbi Enga, ${ }^{1}$ A. Yomon Kayoum, ${ }^{1}$ P. Nkouandou Mache, ${ }^{1}$ \\ L.A. Djomi, ${ }^{2}$ F.A. Mbouangouro, ${ }^{2}$ L.G. Lehman' \\ ${ }^{1}$ Laboratory of Biology and Animal Physiology, Department of Animal Biology, University of \\ Douala, Douala; ${ }^{2}$ Laboratory of Zoology, Department of Biology and Animal Physiology, \\ University of Yaoundé I, Yaoundé, Cameroon
}

\begin{abstract}
Baseline entomological information should be collected before the implementation of industrial projects in malaria endemic areas. This allows for subsequent monitoring and evaluation of the project impact on malaria vectors. This study aimed at assessing the vectorial system and malaria transmission in two ecologically different villages of the South-Cameroon forest bloc targeted for the creation of an agro-industrial complex.
\end{abstract}

Correspondence: Patrick Ntonga Akono, Laboratory of Animal Biology, Department of Animal Biology, Faculty of Science, University of Douala, P.O. Box 2701 Douala, Cameroon.

Tel:. +237.677.74.56.54.

E-mail: patakono2000@yahoo.fr

Key words: Malaria transmission; Anopheles; degraded forest; non-degraded forest; fish ponds; South-Cameroon.

Acknowledgements: the authors would like to thank the authorities and the populations of both localities for their collaboration, as well as Dr. Achille Biwole for preparing the map of the study area.

Contributions: LGL was the overall coordinator of the study. PNA designed the study. OENH, MFPN, RN, GTM and LYE, AYK, PNM collected the data. LAD and FAM perform data interpretation. PNA and CT participated in the drafting of this manuscript. CT performs statistical analysis. All authors revised and approved the manuscript.

Conflict interests: The authors declare no potential conflict of interests.

Received for publication: 12 April 2016.

Revision received: 13 November 2016.

Accepted for publication: 14 November 2016.

(C) Copyright P. Ntonga Akono et al., 2016

Licensee PAGEPress, Italy

Journal of Entomological and Acarological Research 2016; $48: 5930$

doi:10.4081/jear.2016.5930

This article is distributed under the terms of the Creative Commons Attribution Noncommercial License (by-nc 4.0) which permits any noncommercial use, distribution, and reproduction in any medium, provided the original author(s) and source are credited.
For four consecutive seasons in 2013, adult mosquitoes were captured using Human Landing Catch in NDELLE village (located along a main road in a degraded forest with many fish ponds) and KOMBO village (located $5 \mathrm{~km}$ far from the main road in a darker forest and crossed by the Mvobo River). Morpho-taxonomic techniques were used alongside molecular techniques for the identification of mosquito species. ELISA test was used for the detection of circumsporozoite protein antigen of Plasmodium falciparum.

Mosquito biting rate was higher in NDELLE than in KOMBO (28.18 versus 17.34 bites per person per night). Mosquitoes had a strong tendency to endophagy both in NDELLE (73.57\%) and KOMBO (70.21\%). Three anophelines species were identified; An. gambiae, An. funestus s.s and An. moucheti s.s.. An. gambiae and An. funestus s.s. represented the bulk of aggressive mosquitoes in NDELLE ( $\mathrm{n}=10,891 ; 96.62 \%)$. An. gambiae was responsible for $62.6 \%$ and $77.72 \%$ of malaria transmission in KOMBO and NDELLE respectively. Mean entomological inoculation rate recorded in KOMBO and NDELLE were 4.82 and 2.02 infective bites per person per night respectively. Vector control was mainly based on the use of long-lasting insecticidal nets and indoor residual spraying.

The degraded forest environment added to the presence of fishponds resulted in the increase of aggressive mosquito density but not of malaria transmission. The managers should use these data for monitoring and evaluation of the impact of their project; malaria control strategies should be included in their project in order to mitigate the risk of increased malaria transmission as a result of the implementation of their projects.

\section{Introduction}

Vector control remains an important component in the fight against malaria in endemic countries. According to many authors, vector control is one of the first prevention methods (Ross, 1911; WHO, 1994). However, the choice of an appropriate vector control strategy is based on sound knowledge of systematics and bio-ecology of vectors as well as their susceptibility to the various insecticides recommended by the World Health Organisation (WHO). Many studies have shown that the distribution of malaria is closely related to eco-climatic and hydrographic conditions (Dossou-Yovo et al., 1998; Carnevale \& Robert, 2009). For decades, the epidemiological map of malaria in Africa as well as in Cameroon is summarized into two main distribution areas; the equatorial zone where transmission is perennial, driven by $A n$. 
gambiae s.s. and the tropical zone with seasonal transmission essentially driven by An. arabiensis (Same-Ekobo, 1997). Beside the characteristics of these two main areas that determine the density and distribution of the Anopheles fauna responsible for malaria transmission, it is necessary to consider the particular situations encountered in large cities, villages, areas with dams and agricultural areas. Indeed, the increasing population observed in African countries in recent decades has triggered various development projects including agro-pastoral activities to ensure social and dietary well-being. Changes to the environment even at small scale can affect mosquito population as well as malaria transmission (Nzeyimana et al., 2002). However, an objective evaluation of the impact of these projects requires baseline entomological data collected before their implementation.

KOMBO and NDELLE are two villages of the AYOS health district (Cameroon). NDELLE is a village located along a main road, in a degraded forest with many fishponds meanwhile. KOMBO village is located $5 \mathrm{~km}$ far from the main road, in a darker forest, crossed by the Mvobo river. Both villages are targeted by the AYOS city council for the creation of an agro-industrial complex covering up to 25 hectares in KOMBO and 35 hectares in NDELLE. The implementation of this project as from February 2013 would obviously result in important ecological changes with possible consequences on the health of local populations. The project may have mild impact on anopheline proliferation and malaria transmission in NDELLE, given the anthropic face of the village, very favourable to the proliferation of Anopheles. In KOMBO however, the deforestation and anthropization that would result from the implementation of this project could lead to the proliferation of An. gambiae s.l. (heliophilic species) following the increase in sunshine of mosquito breeding sites. This study assesses agressive mosquito diversity and malaria transmission levels in KOMBO and NDELLE.

\section{Materials and methods}

\section{Description of study sites}

The study was conducted in the Ayos health district $\left(03^{\circ} 54^{\prime} \mathrm{N}, 12^{\circ}\right.$ $31^{\prime} \mathrm{E}$ ), an area of degraded forest of South Cameroon (Figure 1). Ayos is in the equatorial area with a Guinean type climate including two rainy seasons (September to November and March to June) alternating with two dry seasons (December to February and July-August). Meteorological data recorded during the past 5 years show an average annual rainfall of $1980.5 \mathrm{~mm} /$ year, average annual temperatures of $26^{\circ} \mathrm{C}$ and an average humidity rate of $80 \%$ (National Meteorology Service of Cameroon, 2014). Winds are frequent and humid, blowing from south-west to west and from north to west for stronger winds (Wété et al., 2003). The hydrographic network is dense, consisting of swampy low lands and many small streams that flow into the river Nyong.

The survey was conducted in two villages of the Ayos health district, precisely NDELLE and KOMBO. NDELLE is a village of about 1500 inhabitants located along a road whose recent construction has led to significant deforestation and the creation of numerous shoals on either side of the road. The village is highly anthropized as confirmed by the presence of cultivated lands and the destruction of the forest. It is also characterized by the presence of fishponds covering a surface of about 5 hectares. Oreochromis niloticus Linnaeus, 1758 (Tilapia) and Clarias gariepinus Burchell, 1822 (catfish) are the main fish species farmed in these ponds (MINEPIA 2009). KOMBO is a village of about 700 inhabitants located 5 $\mathrm{km}$ far from the road, in a darker forest with very little cultivated lands. The village is little anthropized with the presence of numerous trees over $10 \mathrm{~m}$ height and a canopy that often shelters from sun beams. It is crossed by the Mvobo stream, which flows, into the river Nyong. This

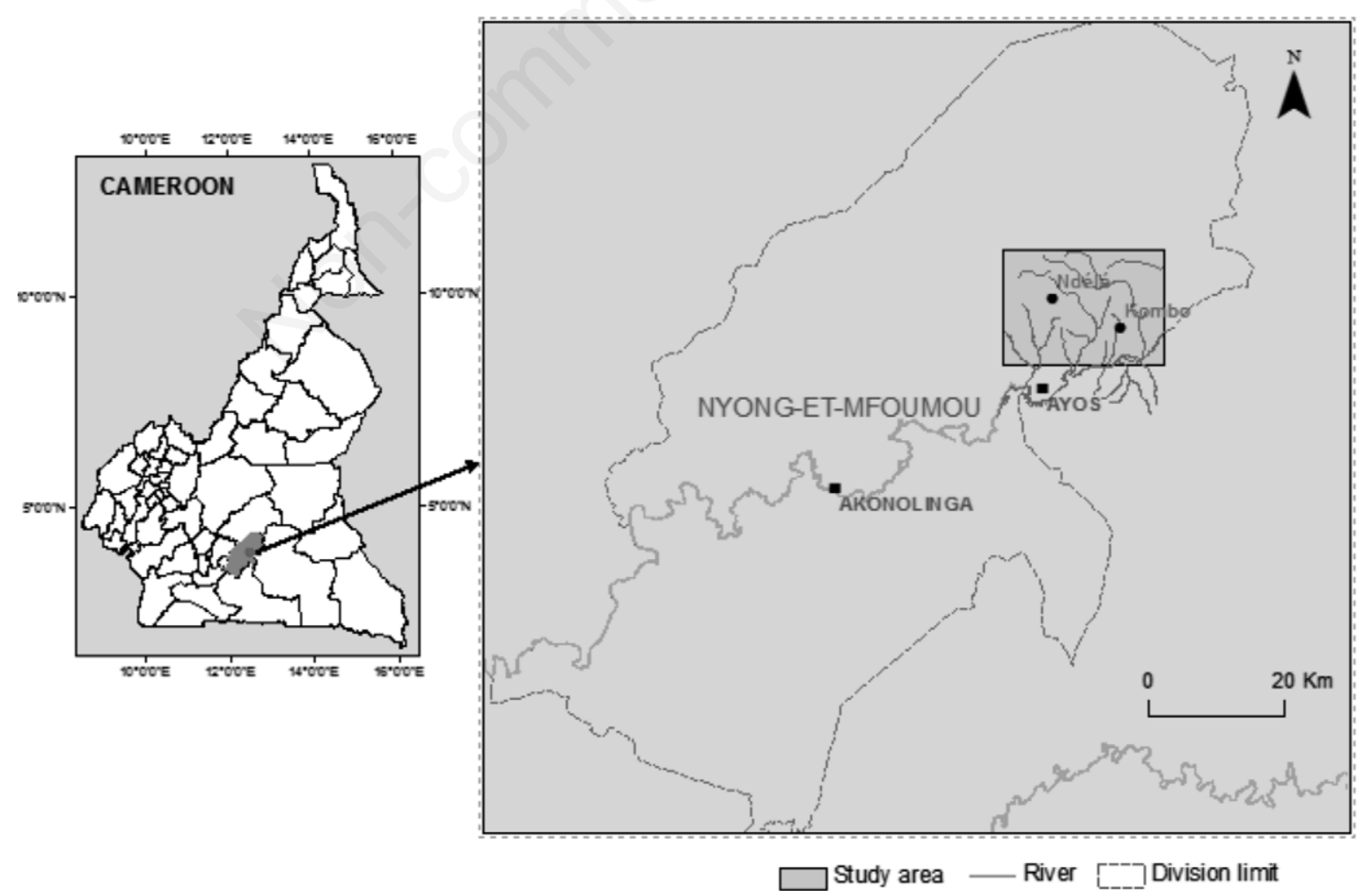

Figure 1. Map of the study area. 
river hosts Gambusia affinis Baird and Girard, 1853; a species known for its predatory skills against Anopheles larvae.

Populations in the two villages are mainly indigenous, belonging to the Mvog-Abada and Yetenga ethnics. They live on agriculture, hunting and fishing. There is no large-scale livestock breeding, though some dogs, cats, pigs and chickens wander through the villages. Malaria cases are usually cared for in the Ayos District Hospital. Prevention is ensured by the use of insecticidal sprays and long lasting insecticidal nets distributed in 2011. Many of these mosquito nets however present with holes.

\section{Capture of adult mosquitoes}

Ten residential houses located nearby major mosquito breeding sites were selected in each of the villages, upon the approval of residents. The sampling technique used for capturing female adult mosquitoes was nocturnal human landing catch on volunteers, indoors and outdoors. Catches were performed each season in 2013, for 5 consecutive days per season, in both study sites simultaneously. In each of the residences, 2 capturers were working in turn in two shifts; one from 6 p.m. to midnight and the other from midnight to 6 a.m. A total of 100 volunteers were used per season in each of the study site. During the capture period, a window or door was left slightly opened. Mosquitoes were morphologically identified to species following the taxonomic keys then stored in silicagel containing Eppendorf tubes at $-20^{\circ} \mathrm{C}$, for subsequent laboratory analysis (Gillies \& De Meillon, 1968; Gillies \& Coetzee, 1987; Jupp, 1996).

\section{Laboratory analysis}

Heads and thoraces of some specimens of adult female Anopheles mosquitoes were analysed for the presence of sporozoite of malaria parasites through the detection of the circumsporozoite protein (CSP), by the ELISA technique (Burkot et al,. 1984; Wirtz et al., 1987). All positive samples were re-tested to confirm the results. DNA extracted from legs and wings was used for biomolecular identification of mosquitoes. Species and molecular forms of An. gambiae complex were identified by a PCR-based method (Fanello et al., 2002). Species of An. funestus, An. nili and An. moucheti groups were identified by the use of PCR-based methods (Cohuet et al., 2003; Kengne et al., 2003; Kengne et al., 2007).

\section{Physico-chemical analysis of water from breeding sites}

Orion $^{\text {TM }} 5$-star portable multi-parameter (Thermo-Scientific) was used to determine physico-chemical parameters including $\mathrm{pH}$, conductivity ( $\mu \mathrm{S} / \mathrm{cm})$, salinity, TDS (mg/L), turbidity (NTU) and dissolved oxygen (\%). A thermometer was used to measure the temperatures of water. Aquatic macro-invertebrates were sampled with a kick-net with a mesh of $2.5 \mathrm{~mm}$ in diameter.

\section{Statistical analysis of data}

Biting rate (number of bites per person per night or $\mathrm{b} / \mathrm{p} / \mathrm{n}$ ) was calculated as the number of mosquitoes caught in one night divided by the number of capturers. The infection rate (\%) was calculated as the number of infected Anopheles female mosquitoes divided by the total number of Anopheles analyzed times 100. The entomological inoculation rate (EIR, number of infected bites per person per night, $\mathrm{ib} / \mathrm{p} / \mathrm{n}$ ) was calculated as the cross product of infection rate and biting rate. Statistical analyses were performed with SPSS software (version 19.0 for Windows, SPSS Inc., Chicago, IL, USA). The Wilcoxon test was used to compare the aggressive densities and average entomological inoculation rates between species, months and study sites.

\section{Informed consent and ethical clearance}

This study received administrative clearance from local authorities. Volunteers aged 20 to 30 years were recruited in the local community and trained on the anthropophilic mosquitoes capture technique. Informed consent was obtained from each volunteer involved in the study. Prior to the capture, selected volunteers were immunized against yellow fever; they also received antimalarial chemoprophylaxis consisting in 3 tablets of sulphadoxine-pyrimethamine (500/25 mg).

\section{Results}

\section{Mosquito diversity in the study sites}

A total of 18208 female adult mosquitoes of 11 species were caught in the two study sites (Table 1). The Anophelinae ( $\mathrm{n}=17,553 ; 96.40 \%)$

Table 1. Female adult mosquitoes captured on volunteer in NDELLE and KOMBO.

\begin{tabular}{|c|c|c|c|c|c|c|c|c|c|}
\hline Species & Indoors & $\begin{array}{l}\text { NDELLE } \\
\text { Outdoors }\end{array}$ & $\begin{array}{l}\text { Nur } \\
\text { Total }\end{array}$ & $\begin{array}{l}\text { emale adu } \\
\text { Indoors }\end{array}$ & $\begin{array}{l}\text { mosquitoe } \\
\text { KOMBO } \\
\text { Outdoors }\end{array}$ & $\begin{array}{l}\text { captured } \\
\text { Total }\end{array}$ & Indoors & $\begin{array}{l}\text { Both sites } \\
\text { Outdoors }\end{array}$ & Total n. (\%)* \\
\hline An. gambiae & 7194 & 2499 & 9693 & 3340 & 1495 & 4835 & 10,534 & 3994 & $14,528(79.78)$ \\
\hline An. funestus s.s & 845 & 353 & 1198 & 620 & 248 & 868 & 1465 & 601 & 2066 (11.34) \\
\hline An. moucheti s.s & - & - & - & 728 & 231 & 959 & 728 & 231 & $959(5.26)$ \\
\hline Cx.pipiens & 146 & 79 & 225 & 17 & 11 & 28 & 163 & 90 & $253(1.38)$ \\
\hline Cx. duttoni & 46 & 26 & 72 & 33 & 15 & 48 & 79 & 41 & $120(0.65)$ \\
\hline Cx. zombaensis & - & - & - & 11 & 2 & 13 & 11 & 2 & $13(0.06)$ \\
\hline Cx. univittatus & 5 & 0 & 5 & - & - & - & 5 & 0 & $5(0.03)$ \\
\hline Ae. albopictus & - & - & - & 121 & 64 & 185 & 121 & 64 & $185(1.06)$ \\
\hline Ae. simpsoni & 10 & 6 & 16 & - & - & - & 10 & 6 & $16(0.09)$ \\
\hline Ae. furcifer & 3 & 2 & 5 & - & - & - & 3 & 2 & $5(0.03)$ \\
\hline M. uniformis & 44 & 14 & 58 & - & - & - & 44 & 14 & $58(0.32)$ \\
\hline \multirow[t]{2}{*}{ Total } & 8293 & 2979 & 11,272 & 4870 & 2066 & 6936 & 13,163 & 5045 & $18,208(100)$ \\
\hline & & $\mathrm{Sl}=8$ & & & $S 2=7$ & & & $S=11$ & \\
\hline
\end{tabular}

\footnotetext{
$\%$, percentage; $\mathrm{S}$, number of species.
} 
occupy most of the general mosquito wildlife. The Culicinae $(n=655$; $3.60 \%$ ) were less represented.

\section{Degraded forest site (NDELLE)}

A total of 11,272 female adult mosquitoes of 8 species were captured in NDELLE (Table 1). An. gambiae (lone species of the Gambiae complex out of 3000 specimens successfully identified by the PCR technique) and $A n$. funestus s.s. (lone species of the Funestus group out of 500 specimens successfully identified by PCR technique) are the only aggressive species of anopheles in this locality. The Anopheles species represents the bulk of the local mosquito wildlife $(\mathrm{n}=10,891 ; \%=96.62)$. The Culicinae are represented by Culex duttoni, Cx. pipiens, Cx. univittatus, Aedes simpsoni, Ae. furcifer and Mansonia uniformis $(\mathrm{n}=381 ; \%=3.38)$ (Table 1$)$.

\section{Non-degraded forest site (KOMBO)}

A total of 6936 female adult mosquitoes belonging to 7 species were captured in KOMBO (Table 1). An. gambiae (lone species of the Gambiae complex out of 3000 specimens successfully identified by the PCR technique), An. funestus s.s. (lone species of the Funestus group out of 500 specimens successfully identified by PCR technique) and $A n$. moucheti s.s (lone species of the Moucheti group out of 300 specimens successfully identified by the PCR technique) are the only aggressive species of anopheles in the locality. The Anopheles species represent the bulk of the local mosquito wildlife ( $\mathrm{n}=6662 ; \%=96.05)$. The Culicinae are represented by Culex pipiens, $C x$. zombaensis, Cx. duttoni and Aedes albopictus $(\mathrm{n}=274 ; \%=3.95)$ (Table 1).

\section{Comparison of diversity in both sites}

The degraded forest site (NDELLE; $n=11,272 ; \%=61.9$ ) recorded a significantly larger number of aggressive mosquitoes than non-degraded forest site $(\mathrm{KOMBO} ; \mathrm{n}=6936 ; \%=38.1)(\mathrm{P}=0.01)$. However, the difference between the number of species recorded in both sites was not significant $(\mathrm{P}=0.8)$. In both sites, the number of captured mosquitoes was higher indoors than outdoors $(\mathrm{P}<0.0001)$.

\section{Biting rate and their variations}

\section{Degraded forest site (NDELLE)}

A total of 11,272 female mosquitoes were captured in 400 men night catches. The overall average biting rate recorded is $28.18 \mathrm{~b} / \mathrm{p} / \mathrm{n}$, that is $41.46 \mathrm{~b} / \mathrm{p} / \mathrm{n}$ indoors and $14.89 \mathrm{~b} / \mathrm{p} / \mathrm{n}$ outdoors. Anopheles mosquitoes contribute $96.61 \%$ of these biting rates, the remaining $3.39 \%$ being insured by Culicinae. An. gambiae appears to be the most aggressive species $(24,23 \mathrm{~b} / \mathrm{p} / \mathrm{n})$, followed by An. funestus s.s. (2.99 b/p/n). Compared to August, biting rates were significantly higher in January $(\mathrm{P}=0.043)$, April $(\mathrm{P}=0.04)$ and October $(\mathrm{P}=0.04)$ (Table 2).

\section{Non-degraded forest site (KOMBO)}

A total of 6,936 female mosquitoes were captured in 400 men night catches. The overall average biting rate recorded is $17.34 \mathrm{~b} / \mathrm{p} / \mathrm{n}$ that is $24.35 \mathrm{~b} / \mathrm{p} / \mathrm{n}$ indoors and $10.33 \mathrm{~b} / \mathrm{p} / \mathrm{n}$ outdoors (Table 2 ). Anopheles mosquitoes ensure $96.06 \%$ of the aggressive activity, the remaining $3.94 \%$ being insured by Culicinae. An. gambiae appears to be the most aggressive species $(12.08 \mathrm{~b} / \mathrm{p} / \mathrm{n})$, followed by An. moucheti s.s. $(2.39 \mathrm{~b} / \mathrm{p} / \mathrm{n})$ and An. funestus s.s. ( $2.17 \mathrm{~b} / \mathrm{p} / \mathrm{n})$. Biting rates were higher in April and August (small dry and small rainy seasons) and are lower in January and October (main dry and main rainy seasons) (Table 2).

\section{Comparison of biting rates}

The overall average daily biting rate recorded is $17.34 \mathrm{~b} / \mathrm{p} / \mathrm{n}$ in the non-degraded forest site and $28.18 \mathrm{~b} / \mathrm{p} / \mathrm{n}$ in the degraded forest site. There is a significant difference between the overall average biting rate recorded in both sites $(\mathrm{P}=0.01)$. Moreover, endophilic mosquitoes were significantly more abundant than exophilic mosquitoes in both study sites $(\mathrm{P}<0.0001)$ (Table 3$)$.

\section{Infection rate and malaria vectors}

\section{Non-degraded forest site (KOMBO)}

In the non-degraded forest site, a total of 1333 female Anopheles mosquitoes belonging to 3 species were tested with the ELISA CSP assay. Mean annual infection rates were $5.3 \%(n=51) ; 10.3 \%(n=18)$ and $6.2 \%(\mathrm{n}=12)$ for An. gambiae, An. funestus s.s. and An. moucheti s.s. respectively (Table 4). The number of infected endophilic females was significantly higher than that of infected exophilic females $(\mathrm{P}<0.0001)$. Infected females were captured in all seasons. Plasmodium falciparum was the only plasmodium species identified in infected female mosquitoes.

Table 2. Number of mosquitoes captured on volunteers and variation of biting rates (b/p/n) in NDELLE and KOMBO.

\begin{tabular}{|c|c|c|c|c|c|c|c|c|c|c|c|c|c|c|c|c|}
\hline \multirow{3}{*}{ Species } & \multicolumn{8}{|c|}{ NDELLE } & \multicolumn{8}{|c|}{ KOMBO } \\
\hline & \multicolumn{2}{|c|}{ January } & \multicolumn{2}{|c|}{ April } & \multicolumn{2}{|c|}{ August } & \multicolumn{2}{|c|}{ October } & \multicolumn{2}{|c|}{ January } & \multicolumn{2}{|c|}{ April } & \multicolumn{2}{|c|}{ August } & \multicolumn{2}{|c|}{ October } \\
\hline & Capt.* & $\mathrm{BR}^{\circ}$ & Capt. & BR & Capt. & BR & Capt. & BR & Capt. & BR & Capt. & BR & Capt. & BR & Capt. & $\mathrm{BR}$ \\
\hline An. gambiae & 2761 & 27.61 & 4035 & 40.35 & 532 & 5.32 & 2365 & 23.65 & 800 & 8 & 1750 & 17.5 & 1635 & 16.35 & 650 & 6.5 \\
\hline An. funestus s.s & 363 & 3.63 & 502 & 5.02 & 131 & 1.31 & 202 & 2.02 & 58 & 0.58 & 362 & 3.62 & 400 & 4 & 48 & 0.48 \\
\hline An. moucheti s.s & - & - & - & - & - & - & - & - & 435 & 4.35 & 103 & 1.03 & 115 & 1.15 & 306 & 3.06 \\
\hline Cx.pipiens & 45 & 0.45 & 138 & 1.38 & 25 & 0.25 & 17 & 0.17 & 15 & 0.15 & 7 & 0.07 & 0 & 0 & 6 & 0.06 \\
\hline Cx. duttoni & 15 & 0.15 & 36 & 0.36 & 21 & 0.21 & 0 & 0 & 15 & 0.15 & 6 & 0.06 & 7 & 0.07 & 20 & 0.2 \\
\hline Cx. zombaensis & - & - & - & - & - & - & - & - & 5 & 0.05 & 3 & 0.03 & 1 & 0.01 & 4 & 0.04 \\
\hline CX. univittatus & 0 & 0 & 5 & 0.05 & 0 & 0 & 0 & 0 & - & - & - & - & - & - & - & - \\
\hline Ae. albopictus & - & - & - & - & - & - & - & - & 45 & 0.45 & 28 & 0.28 & 67 & 0.67 & 45 & 0.45 \\
\hline Ae. simpsoni & 2 & 0.02 & 3 & 0.03 & 5 & 0.05 & 6 & 0.06 & - & - & - & - & - & - & - & - \\
\hline Ae. furcifer & 0 & 0 & 4 & 0.04 & 1 & 0.01 & 0 & 0 & - & - & - & - & - & - & - & - \\
\hline M. uniformis & 15 & 0.15 & 32 & 0.32 & 5 & 0.05 & 6 & 0.06 & - & - & - & - & - & - & - & - \\
\hline Total & 3201 & 32.01 & 4755 & 47.55 & 720 & 7.2 & 2596 & 25.96 & 1373 & 13.73 & 2259 & 22.59 & 2225 & 22.25 & 1079 & 10.79 \\
\hline
\end{tabular}

*Capt., number of mosquitoes captured; ${ }^{\circ} \mathrm{BR}$, biting rate. 


\section{Degraded forest site (NDELLE)}

A total of 2,179/10,891 female mosquitoes were tested with the ELISA CSP assay; 35 females were found to be infected with Plasmodium falciparum. Annual average infection rates were $1.4 \%(\mathrm{n}=27)$ and $3.3 \%(\mathrm{n}=8)$ for An. gambiae and An. funestus s.s. respectively (Table 4). The number of infected females was significantly higher inside and outside homes $(\mathrm{P}<0.0001)$. Infected females were captured at each capture season.

\section{Entomological inoculation rates and malaria transmission}

\section{Non-degraded forest site (KOMBO)}

Malaria transmission is ensured by the three anopheles species identified in this site. The average annual EIR recorded is $4.82 \mathrm{ib} / \mathrm{p} / \mathrm{n}$. An. gambiae $(3.02 \mathrm{ib} / \mathrm{p} / \mathrm{n})$ appears to be the major malaria vector in the locality. An. funestus s.s. (1085 ib/p/n) and An. moucheti s.s. (0.72 $\mathrm{ib} / \mathrm{p} / \mathrm{n}$ ) are considered secondary vectors (Table 5). The average EIR was significantly higher for An. gambiae than An. funestus s.s. $(\mathrm{P}<0.0001)$ and An. moucheti s.s. $(\mathrm{P}<0.0001)$.

An. gambiae recorded high EIR in the months of January, August and October (Table 5). EIR were significantly higher indoors than outdoors $(\mathrm{P}=0.04)$.

\section{Degraded forest site (NDELLE)}

Malaria transmission is ensured by the 2 anopheles identified in the site. The average annual EIR recorded is $2.02 \mathrm{ib} / \mathrm{p} / \mathrm{n}$. An. gambiae with an EIR of $1.57 \mathrm{ib} / \mathrm{p} / \mathrm{n}$, appears to be major malaria vector in this locality. An. funestus s.s. $(0.45 \mathrm{ib} / \mathrm{p} / \mathrm{n})$ is regarded as a secondary vector (Table 5$)$. The average EIR are significantly different between An. gambiae and An. funestus s.s. ( $\mathrm{P}=0.03)$. An. gambiae EIR was at its peak in January (Table 5).

\section{Comparison of entomological inoculation rate}

The overall average EIR recorded was $4.82 \mathrm{ib} / \mathrm{p} / \mathrm{n}$ and $2.02 \mathrm{ib} / \mathrm{p} / \mathrm{n}$, in the non-degraded forest site and in the degraded forest site respectively. The difference between the overall average daily EIR in both sites is significant $(\mathrm{P}=0.002)$. EIR were significantly higher indoors and outdoors in the two study sites (Table 3).

\section{Physico-chemical parameters of breeding sites}

Fish ponds and river bank breeding sites are acidic $(4.5 \leq \mathrm{pH} \leq .7,3)$ and adequately oxygenated (dissolved oxygen from 6.9 to $11.2 \mathrm{mg} / \mathrm{L}$ ). The solubilization ratio is low ( $95.3 \mathrm{mg} / \mathrm{L} \leq \mathrm{TDS} \leq 170.4 \mathrm{mg} / \mathrm{L})$. These parameters are favourable for mosquito larvae survival and growth. However, the riverbank site (non-degraded forest site) hosts a larvivorous fish species (Gambusia affinis) and is richer in aquatic macro-invertebrates than the fish-farming site (degraded forest site) (Table 6).

\section{Discussion}

This study compared aggressive mosquito diversity and the transmission of human malaria in a non-degraded forest and degraded forest sites in a rural area of the South of Cameroon. It appears that the mosquito fauna in both sites is abundant and diverse. It consists of the genus Culex, Aedes, Anopheles and Mansonia. However, Anophelinae are more abundant than Culicinae (Table 1). This is consistent with findings by many authors who have carried out similar studies in tropical African villages (Robert et al., 1998). This may be bound to the nature of the breeding sites that are less polluted and have low content of dissolved organic matter. Molecular techniques coupled with conventional taxonomy methods have shown the presence of three species of

Table 3. Comparison of biting rates and entomological inoculation rates in the study sites.

\begin{tabular}{rlccc} 
& & & & Study site \\
Biting rate (b/p/n) & NDELLE & KOMBO & 0.001 \\
& Indoor & 41.46 & 24.35 & 0.13 \\
& Outdoor & 14.89 & 10.33 & - \\
& P & $<0.0001$ & $<0.0001$ & 0.01 \\
EIR (ib/p/n) & Total & 28.18 & 17.34 & 0.12 \\
& Indoor & 1.41 & 3.49 & $<0.0001$ \\
& Outdoor & 0.61 & 1.33 & - \\
& P & 0.001 & 4.0001 & 0.002 \\
\hline
\end{tabular}

EIR, entomological inoculation rates.

Table 4. Number of infected mosquitoes and variations of infection rates in NDELLE and KOMBO.

\begin{tabular}{|c|c|c|c|c|c|c|c|c|}
\hline \multirow[b]{2}{*}{$\begin{array}{l}\text { Month of } \\
\text { survey }\end{array}$} & \multicolumn{3}{|c|}{ NDELLE } & \multicolumn{5}{|c|}{$\mathrm{KOMBO}$} \\
\hline & $\begin{array}{r}\text { An. } \\
\text { Tested 1 } \\
\text { (infected) }\end{array}$ & $\begin{array}{l}\text { gambiae } \\
\text { Infection rate } \\
(95 \% \mathrm{CI})\end{array}$ & $\begin{array}{l}\text { An. funestus s.s. } \\
\text { e Tested Infection rate } \\
\text { (infected) }(95 \% \mathrm{CI})\end{array}$ & $\begin{array}{l}\text { An. gambiae } \\
\text { Tested Infection rate } \\
\text { (infected) }(95 \% \mathrm{CI})\end{array}$ & $\begin{array}{l}\text { An. } f \\
\text { (infected) }\end{array}$ & $\begin{array}{l}\text { Infection rate } \\
(95 \% \mathrm{CI})\end{array}$ & $\begin{array}{l}\text { An. } m \\
\text { Tested } \\
\text { (infected }\end{array}$ & $\begin{array}{l}\text { Infection rate } \\
\text { Inch } \\
(95 \% \mathrm{CI})\end{array}$ \\
\hline January & $553(11)$ & $2.0(1.6-2.3)$ & $4.1(3.8-4.4)$ & $160(15) \quad 9.4(8.7-10.2)$ & $12(1)$ & $8.3(7.3-9.2)$ & $87(4)$ & $4.6(3.9-5.3)$ \\
\hline April & $807(5)$ & $0.6(0.5-0.7)$ & $2.0(1.6-2.3)$ & $2.3(1.9-2.7)$ & $73(7)$ & $9.6(9.1-10.1)$ & $21(2)$ & $9.5(8.2-10.7)$ \\
\hline August & $107(8)$ & $7.4(6.9-7.9)$ & $7.7(7.1-8.2)$ & $2.7(1.9-3.6)$ & $80(8)$ & $10(8.7-11.2)$ & $23(4)$ & $17.4(13.9-20.9)$ \\
\hline October & $473(3)$ & $0.6(0.5-0.7)$ & $2.5(1.9-3.1)$ & 130 (19) $14.6(13.1-16.2)$ & $10(2)$ & $20(17.3-22.5)$ & $62(2)$ & $3.2(2.4-4.1)$ \\
\hline Overall & $1939(27)$ & $1.4(1.1-1.7)$ & $3.3(3.0-3.5)$ & $5.3(4.3-6.2)$ & $174(18)$ & $10.3(8.6-11.9)$ & $192(12)$ & $6.2(5.7-6.9)$ \\
\hline
\end{tabular}


anopheles out of the forty Anopheles species identified in Cameroon (Hervy et al., 1998). These are An. gambiae, An. funestus s.s. and An. moucheti s.s. Table 1 shows that An. gambiae is twice as frequent in NDELLE than in KOMB0. This species has been reported by many authors as the major malaria vector in degraded forest area in tropical Africa (Languillon et al., 1956; Akono et al., 2014). The adaptation of this species could be explained by the presence of sunlit breeding sites. In fact, the degraded environment in NDELLE favour better exposure of breeding sites to sunlight An. gambiae being known as an heliophilic species. On the other hand, these breeding sites are less polluted, and made of freshwater collections of various dimensions. Females $A n$. moucheti s.s. were only captured in the non-degraded forest site. The presence of this species appears to depend on the Mvobo river. In fact, An. moucheti s.s. larvae live preferentially in permanent slow-flowing waters more or less rich in plant species like Pistia sp (Njan Nloga et al., 1993). In addition, Anopheles funestus s.s. larvae are heliophobic though having same environmental requirements as those of An. gambiae (Hamon et al., 1956). The presence of some shaded breeding sites with an upright vegetation and low dissolved organic matter rate in the study sites may explain the presence of this species in houses.

Biting rates were significantly higher in the degraded forest sites. In addition to the density of the forest that limits the exposure of breading sites to sunlight and thus the abundance of An. gambiae larvae in KOMBO, the difference of mosquito abundance between the sites could be related to differences in density of macro-invertebrates and aquatic vertebrates, which may regulate the populations of aquatic mosquito larvae by exerting predation on them or depriving them from essential nutrient found in the site (Mereta et al., 2012). Lepidoptera, beetles and frogs larvae are long known for their impact on aquatic mosquito fauna (Humberto \& Ariadna, 2007). A comparison between the two sites showed a higher abundance of macro-invertebrates in the Mvobo river; this may explaining the weak biting rate recorded in non-degraded forest site compared with the degraded forest site. Furthermore, Gambusia affinis, a larvivorous fish species originating from the south of the United States of America lives in the Mvobo river. This aquatic vertebrate has often been captured by fishermen in the area. It has been used successfully in some countries for the biological control of mosquitoes. In India for instance, its introduction in rice paddies has resulted in an $88 \%$ reduction of mosquito larvae population. This fish species, capable of consuming over 165 Anopheles larvae in two hours (Lemasson, 1957), could well be regarded as one of the regulatory factors of mosquito biting rates in this site. Captured mosquitoes were more endophilic than exophilic. The feeding behavior of vectors appears to be subservient to the behavior of the inhabitants of the study sites. In fact, inhabitants of the study sites carry out agricultural activity during day time; they go to bed early enough. Moreover, in the non-degraded forest site, the fishermen go to bed early, because they start fishing activities before sunrise. This habit of early sleeping forces mosquitoes to mostly seek blood meal indoors than outdoors.

Seasonal fluctuations of biting rates for An. gambiae and An. funestus s.s. follow the same trend and are associated with the operations in the fish ponds of degraded forest site. The results showed low biting rates in August. This result could be explained by the fact that August is the period during which in NDELLE, fishponds are drained. This maintenance of fish ponds resulted in the interruption of the mosquito larvae development cycle, thereby contributing to lower biting rate. On the reverse, in the non-degraded forest site, the seasonal variations of biting rates of An. gambiae and An. funestus s.s. are influenced by the

Table 5. Variation of entomological inoculation rate (ib/p/n) in NDELLE and KOMBO.

\begin{tabular}{|c|c|c|c|c|c|}
\hline Month of survey & $\begin{array}{l}\text { NDELLE } \\
\text { An. gambiae }\end{array}$ & $\begin{array}{c}\mathrm{KOMBO} \\
\text { An. funestus s.s. }\end{array}$ & An. gambiae & An. funestus s.s. & An. moucheti s.s. \\
\hline January & 2.71 & 0.73 & 3.6 & 0.03 & 1.09 \\
\hline April & 2.02 & 0.5 & 1.75 & 1.81 & 0.46 \\
\hline August & 1.86 & 0.52 & 2.45 & 2 & 0.98 \\
\hline October & 0.71 & 0.3 & 4.87 & 0.48 & 0.46 \\
\hline Overall & 1.57 & 0.45 & 3.02 & 1.085 & 0.72 \\
\hline
\end{tabular}

$\mathrm{ib} / \mathrm{p} / \mathrm{n}$, infective bites per person per night.

Table 6. Physicochemical parameters of mosquito breeding sites.

\begin{tabular}{|c|c|c|c|c|}
\hline \multirow[t]{3}{*}{ Parametres } & \multicolumn{4}{|c|}{ Breeding sites } \\
\hline & \multicolumn{2}{|c|}{ NDELLE } & \multicolumn{2}{|c|}{ KOMBO } \\
\hline & Mean \pm SE & Range & Mean \pm SE & Range \\
\hline Dissolvedoxygen & $7.2 \pm 1.2$ & $6.9-8.3$ & $8.9 \pm 0.8$ & $8.6-11.2$ \\
\hline $\mathrm{pH}$ & $6.03 \pm 0.2$ & $5.3-6.7$ & $6.9 \pm 0.7$ & $4.5-7.3$ \\
\hline Salinity (\%) & $0.07 \pm 0.03$ & $0.05-0.1$ & $0.08 \pm 0.02$ & $0.06-0.1$ \\
\hline Conductivity $(\mu \mathrm{S} / \mathrm{cm})$ & $280.2 \pm 5.6$ & $255.7-290.5$ & $273.5 \pm 6.2$ & $250.3-300.7$ \\
\hline Water temperature $\left({ }^{\circ} \mathrm{C}\right)$ & $26.9 \pm 2.7$ & $23.2-31.5$ & $24.1 \pm 3.5$ & $22.3-27.6$ \\
\hline Total dissolved solids (mg/L) & $150.6 \pm 2.6$ & $140.4-170.4$ & $106.3 \pm 1.2$ & $95.3-114.9$ \\
\hline Turbidity (NTU) & $30.2 \pm 1.7$ & $26.0-37.0$ & $28.4 \pm 3.7$ & $23-32$ \\
\hline Aquatic plants & $(+)$ & - & $(+++)$ & - \\
\hline Gambusia affinis & $(-)$ & - & $(+++)$ & - \\
\hline Aquaticinvertebrates & $(-)$ & - & $(+++)$ & - \\
\hline
\end{tabular}


rainfall. January is the long dry season, characterized by the drying up of most of the existing temporary water collections in the site; which explains the low biting rates recorded in this period. The spacing of rainfalls observed in April and August allows for the reconstitution of previously drained breeding sites, explaining the high biting rates in this time of year. The abundance and regularity of rainfalls in October favored the leaching of breeding sites and the larvae they contain, resulting in lower biting rates observed at this time of the year. The survival of An. moucheti s.s. is especially related to aquatic plant species such as Pistia sp. (Njan Nloga et al., 1993). For some years, the inhabitants carry out weeding of the river Mvobo to get the bed rid of invasive plant species. This weeding activity by local residents carried out in April and August each year result in the disruption of the ecology of An. moucheti s.s. larvae of resulting in a lower biting rate of $A n$. moucheti s.s. in the study site at these periods. Similar patterns of seasonal fluctuations in aggressive Anopheles mosquito densities have been reported in other villages crossed by rivers, noting influence of these rivers in malaria transmission (Akono et al., 2014).

The CSP ELISA tests revealed that malaria transmission is maintained throughout the year in the study sites, driven by An. gambiae, An. funestus s.s and An. moucheti s.s.. In both sites, An. gambiae appears to be the major malaria vector. It is followed in this role by $A n$. funestus s.s. and An. moucheti s.s. in the non-degraded forest site and An. funestus s.s. only in the degraded forest site. This is consistent with findings in most villages of forest areas in tropical Africa where An. gambiae is the most adapted species and the major malaria (Languillon et al., 1956). An. gambiae is the only species of the Gambiae complex that was identified and found to be infected in the study sites. This result is all the more reliable as other studies have reported that $A n$. gambiae flourishes better and transmits malaria in sunlit forest context (Akono et al., 2014), in contrast to An. coluzzii which tends to fit better in polluted towns of tropical Africa as well as in brackish water collections (Antonio-Nkondjio et al., 2012; Overgaard et al., 2012). An. moucheti s.s. and An. funestus s.s. are secondary malaria vectors in the study area. Studies on their roles in the transmission have been conducted by many authors (Njan Nloga et al., 1993; Antonio-Nkondjio et al., 2008; Akono, 2011). In some localities, An. moucheti s.s. has shown to be a locally important vector (Njan Nloga et al., 1993). While in others, An. funestus s.s. was reported as subsequent in time to An. gambiae in its role as major vector malaria (Dossou-Yovo, 1998; Akono, 2011). The results also show that the entomological inoculation rate (EIR) vary with sites and months. A comparative analysis shows that in October, the non-degraded forest site record higher EIR than the degraded forest site. This could be justified by differences in aggressive mosquito densities observed in the two sites in this period. In fact, the leaching of Anopheles larvae that occurs with heavy rainfall results in a very low biting rate and subsequent increase in the proportion of infected female anopheles in the general mosquito community. Ultimately, the overall average EIR recorded in the non-degraded forest and in the degraded forest sites were respectively $4.82 \mathrm{ib} / \mathrm{p} / \mathrm{n}$ and 2.02 $\mathrm{ib} / \mathrm{p} / \mathrm{n}$. Thus, the degraded forest environment and the presence of many fishponds in NDELLE have led to a proliferation of Anopheles mosquitoes; however, it has not resulted in a significant increase of malaria transmission.

These results should be used for monitoring and evaluation of the impact of the future agro-industrial complex on aggressive mosquito diversity and malaria transmission in these villages. An increase in entomological values of malaria parasite transmission in the course of the implementation of the project should trigger the reinforcing of malaria control strategies by project managers and local authorities, mainly mass distribution of new LLINs and elimination of anopheline breeding sites set up during the earthmoving of the site alongside health education on malaria. The managers should thus include malaria prevention strategies in their project in order to mitigate the risk of increased malaria transmission as a result of the implementation of their projects.

\section{References}

AFRANE Y., KLINKENBERG E., DRECHSEL P., OWUSU-DAAKU K., GARMS R., KRUPPA T., 2004 - Does irrigated urban agriculture influence the transmission of malaria in the city of Kumasi, Ghana? - Acta Trop. 89: 125-134.

AKONO N.P., MBIDA M.J.A., TONGA C., BELONG P., NGO HONDT O.E., MAGNE T.G., PEKA M.F., LEHMAN L.G., 2015 - Impact of vegetable crop agriculture on anopheline agressivity and malaria transmission in urban and less urbanized settings of the south region of Cameroon. . Parasit. Vectors 87: 293.

AKONO N.P., 2011 - Ecologie des Culicidae à Tonga (Ouest-Cameroun) et effets insecticides des huiles essentielles de quelques plantes sur Anopheles gambiae Giles, 1902. - Ph.D. Thesis, University of Yaoundé I, Yaoundé. [In French].

AKONO N.P., TONGA C., KEKEUNOU S., LEHMAN L.G., 2014 - Mosquito species diversity and malaria transmission in Ayos, an area of degraded forest targeted for universal LLIN distribution in southern Cameroon. - Afr. Entomol. 22: 602-610.

ANTONIO-NKONDJIO C., DEFO-TALOM B., TAGNE-FOTSO R., TENEFOSSOG B., NDO C., LEHMAN L.G., TCHUINKAM T., KENGNE P., AWONO-AMBENE P., 2012 - High mosquito burden and malaria transmission in a district of the city of Douala, Cameroon. - BMC Infect. Dis.12: 275.

ANTONIO-NKONDJIO C., NDO, C. KENGNE P., MUKWAYA L., AWONOAMBENE H.P., FONTENILLE D., SIMARD F., 2008 - Population structure of the malaria vector Anopheles mouchet $i$ in the equatorial forest region of Africa. - Malaria J. 7: 120.

BURKOT T., WILLIAMS J., SCHNEIDER I., 1984 - Identification of Plasmodium falciparum infected mosquitoes by double antibody enzyme-linked immunosorbent assay. -Am. J. Trop. Med. Hyg. 33: 783-788.

CARNEVALE P., ROBERT V., 2009 - Les Anophèles-Biologie, Transmission du Plasmodium et Lutte Antivectorielle. - IRD ed. Collections Didactiques, Marseille.

COHUET A., SIMARD F., TOTO J.C., KENGNE P., COETZEE M., FONTENILLE D., 2003 - Species identification within the Anopheles funestus group of malaria vectors in Cameroon and evidence for a new species. - Am. J. Trop. Med. Hyg. 69: 200-205.

DONGUS S., NYIKA D., KANNADY K., MTASIWA D., MSHINDA H., GOSONIU L., DRESCHER A.W., FILLINGER U., TANNER M., KILLEEN G.F., CASTRO M.C., 2009 - Urban Agriculture and Anopheles habitats in Dar Es Salaam, Tanzania. - Geospat. Health 3: $189-210$.

DOSSOU-YOVO J., DOANNIO J.M.C., DIARRASSOUBA S., CHAUVANCY G., 1998 - Impact d'aménagements des rizières dans la ville de Bouaké, Côte d'Ivoire. - Bull. Soc. Exot. 91: 327-333.

FANELLO C., SANTOLAMAZZA F., DELLA TORRE A., 2002 Simultaneous identification of species and molecular forms of Anopheles gambiae complex by PCR-RFLP. - Med. Vet. Entomol. 16: 461-464.

GILLIES M.T., COETZEE M., 1987 - Anophelinae of Africa south of Sahara. - S. Afr. Inst. Med. Res. 55: 1-156.

GILLIES M.T., DE MEILLON B., 1968 - The Anophelinae of Africa South of the Sahara (Ethiopian zoogeographical region). - S. Afr. Inst. Med. Res. 54: 1-343.

HAMON J., ADAM P., GRJEBINE A., 1956 - Les Anophèles de l'ouest de l'Afrique. - Bull. World Health Organ. 15: 565-572.

HERVY J.P., LE GOFF G., GEOFFROY B., HERVE J.P., MANGA L., BRUN- 
HES J., 1998 - Les anophèles de la région afro-tropicale. - ORSTOM Editions, Coll. Didactiques, CD-Rom.

HUMBERTO Q.M., ARIADNA R.C., 2007 - Aquatic Insects as Predators of Mosquito Larvae. - J. Am. Mosq. Control. Assoc. 23: 110-117.

JUPP P.G., 1996 - Mosquitoes of Southern Africa: Culicinae and Toxorhynchitinae. - Ekogilde Pubs.

KENGNE P., ANTONIO-NKONDJIO C., AWONO-AMBENE H., SIMARD F., AWOLOLA T., FONTENILLE D., 2007 - Molecular differentiation of three closely related members of the mosquito species complex Anopheles moucheti, by mitochondrial and ribosomal DNA polymorphism. - Med. Vet. Entomol. 21: 177-182.

KENGNE P., AWONO-AMBENE P., ANTONIO-NKONDJIO C., SIMARD F., FONTENILLE D., 2003 - Molecular identification of the Anopheles nili group of African malaria vectors. - Med. Vet. Entomol. 17: 67-74.

KLINKENBERG E., MCCALL P.J., WILSON M.D., AMERASINGHE F.P., DONNELLY M.J., 2008 - Impact of urban agriculture on malaria vectors in Accra, Ghana. - Malaria J. 7: 151.

LANGUILLON J., MOUCHET J., RIVOLA E., RAGEAU J., 1956 Contribution à l'étude de l'épidémiologie du paludisme dans la région forestière du Cameroun. Paludométrie, espèces plasmodiales, anophélisme, transmission. - Med. Trop. 16: 347-378.

LEMASSON J., 1957 - Chronique piscicole. Pisciculture et paludisme. Bois For. Trop. 56: 58-61.

MERETA S.T., BOETS P., BAYIH A.A., MALU A., EPHREM Z., SISAY A., ENDALE H., YITBAREK M., JEMAL A., DE MEESTER L., GOETHALS P.L.M., 2012 - Analysis of environmental factors determining the abundance and diversity of macro invertebrate taxa in natural wetland of southwest Ethiopia. - Ecolinf. 7: 52-61.

MINEPIA (Ministère camerounais de l'Elevage, des Pêches et des Industries Animales), 2009 - Revue sectorielle d'aquaculture Cameroon.
NATIONAL METEOROLOGY SERVICE OF CAMEROON, 2014 - Rapport annuel. - Cameroon.

NJAN NLOGA A., ROBERT V., TOTO J. C., CARNEVALE P., 1993 Anopheles moucheti vecteur principal du paludisme au sud Cameroun. - Bull. Liais. Doc. OCEAC. 26: 63-67.

NZEYIMANA I., HENRY M.C., DOSSOU-YOVO J., DOANNIO J.M.C., DIAWARA L., CARNEVALE P., 2002 - Epidémiologie du paludisme dans le sud-ouest forestier de la Côte d'Ivoire (région de Taï). Bull. Soc. Pathol. Exot. 95: 89-94.

OVERGAARD H.J., VAMSI P.R., ABAGA S., ABRAHAN M., REDDY M.R., KULKARNI V., SCHWABE C., SEGURA L., KLEINSCHMIDT I., SLOTMAN M. A., 2012 - Malaria transmission after five years of vector control on Bioko Island, Equatorial Guinea. - Parasit. Vectors 253: 2-14.

ROBERT V., DIENG H., LOCHOUARN L., TRAORE S.F., TRAPE J.F., SIMONDON F., FONTENILLE D., 1998 - La transmission du paludisme dans la zone de Niakkhar, Sénégal. - Trop. Med. Int. Health. 3: 667-677.

ROSS R., 1911 - The prevention of malaria. $2^{\text {nd }}$ ed. - Murray, London.

SAME EKOBO A., 1997 - Santé, Climat et Environnement au Cameroun. - Ed. Juley- Sciences, Yaoundé.

WETE J., RADOUX M., TANAWA E., 2003 - Assainissement des eaux usées et risques socio-sanitaires et environnementaux en zone d'habitat planifié de Yaoundé (Cameroun). - Vertig0. 4: 7-10.

WHO, 1994 - Techniques entomologiques pratiques dans la lutte antipaludique. Part I guide du stagiaire. - WHO, Geneve: $77 \mathrm{p}$.

WIRTZ R., ZAVALA F., CHAROENVIT Y., CAMPBELL G.H., BURKOT T.R., SCHNEIDER I., ESSER K.M., BEAUDOIN R.L., ANDRE R.G., 1987 Comparative testing of monoclonal antibodies against Plasmodium falciparum sporozoïtes for ELISA development. - Bull. World Health Organ. 65: 39-45. 